Nadežda Zemaníková

ORCID: 0000-0001-6584-7390

Univerzita Mateja Bela

Banská Bystrica, Slovenská republika

\title{
Mužskost’ ako diskurzívna konštrukcia. Nemecké literárnovedné analýzy mužskosti v 21. storočí
}

https://doi.org/10.34739/clit.2021.15.23

\begin{abstract}
Masculinity as a Discursive Construct. German Literary Analyses of Masculinity in the 21st Century
\end{abstract}

The first studies which introduced the category of masculinity into German literary science in the context of contemporary interdisciplinary gender research, perceiving it as a social and cultural construct, were published shortly after the turn of the century. The paper lays out the basic theoretical approaches to masculinity in literary texts presented in relevant German literary works of the second decade of the 21st century. In contemporary literary analyses, it is not only a question of revealing masculine power structures in literary texts, but also of criticising onesided and stereotypical constructs of male identity. Attention is focused on the combination of masculinity and emotionality, but also on the relationship between masculinity and fatherhood or on the literary reflections of the changes in the conventional status of man as a breadwinner, public actor and creative intellectual. Literary masculinities are understood as products of literary narratives.

Keywords: masculinity, German literary science, discourse, narrativity, emotionality, fatherhood

V rámci rodových štúdií sa výskum mužskosti teší aj v Nemecku už viac ako dve desaţročia záujmu rôznych vedeckých disciplín. Rozpad patriarchálneho symbolického poriadku, tradičných predstáv o silnom, dominantnom mužovi, spochybnenie a zneistenie etablovaných pozícií muža v profesionálnej i rodinnej sfére, považovaných za samozrejmost’ a výrazne identitotvorných, sa v novom tisícročí vníma predovšetkým ako kríza maskulinity, ktorej dôsledkom môže byt’ konceptuálna zmena v prospech rodovej spravodlivosti, či už v podobe plurality reprezentácií 
maskulinity a feminity alebo v podobe transformácie regresívnej mužskosti na progresívnu. Diskurz krízy mužskosti však tiež môže viest'k rekonštrukcii mužskej hegemónie a maskulínnych mocenských štruktúr. Model rozmanitých maskulinít, najmä intenzívne diskutovaný koncept hegemonickej maskulinity austrálskej sociologičky Reawyn Connellovej z osemdesiatych rokov dvadsiateho storočia, úzko previazaný s konceptom moci a neskôr precizovaný ${ }^{1}$, ako aj jej pojem patriarchálnej dividendy boli viacnásobne kriticky reflektované a vytvorili dôležité teoretické rámce novej kritickej sociológie maskulinít. Mužskost’ sa vnich chápe multidimenzionálne pri zohl'adnení ekonomických pomerov, mocenských štruktúr aj emocionálnych vztahohov.

Už v poslednej dekáde dvadsiateho storočia vystriedali v Nemecku paradigmu feministickej literárnej vedy literárnovedné rodové štúdiá a preniesli pozornost’ od esencialisticky chápanej ženskosti na kultúrne konštruovanú rodovú identitu, aby neskôr tzv. queerová teória spochybnila samotný binárny rodový model.

Od devätdesiatych rokov rástol počet publikácií k téme mužskosti v literatúre a umení, ale chýbal komplexný historický prehl’ad konceptov mužskosti a ich premien. Zborník, ktorý v roku 2011 pod názvom zvoleným s alúziou na prvý verš Schillerovej básne Kastraten und Männer [Kastráti a muži] „Ich bin ein Mann! Wer ist es mehr?“ Männlichkeitskonzepte in der deutschen Literatur vom Mittelalter bis zur Gegenwart [„,Som muž! Kto je viac?" Koncepty mužskosti vnemeckej literatúre od stredoveku po súčasnost ${ }^{2}$ ] publikovali Barbara Hindingerová a Martin-M. Langner ${ }^{3}$, mal ambíciu poskytnút takýto prehl'ad a zároveň charakterizovat vývinové línie skúmaných konceptov, preto tiež vpublikácii dominuje používanie ústredného pojmu v pluráli, maskulinity. Štúdie analyzujú mužské rodové koncepty v nemeckej literatúre v prehlade zahŕňajúcom osemsto rokov literárneho vývinu a demonštrujú premenlivost’ oficiálnych mužských vzorcov, ako aj prekvapivú rôznorodost' literárnych mužských postáv.

\footnotetext{
1 R.W. Connell, J.W. Messerschmidt, Hegemonic maskulinity. Rethinking the Concept, „Gender \& Society” 2005, No. 6 (16), s. 829-859. Connellová tiež v predhovore k nemeckému prekladu druhého vydania svojej klúčovej knihy Masculinities zdôrazňuje, že jej intenciou nebolo spájat’ hegemonickú maskulinitu s „hrozivou, nebezpečnou, násilnou mužskostou“. R. Connell, Der gemachte Mann. Konstruktion und Krise von Männlichkeiten, Wiesbaden 2015, s. 22.

${ }^{2}$ Slovenské verzie názvov zdrojov, ako aj všetky pasáže citované z nemeckých zdrojov uvádzam vo vlastnom preklade bez explicitného označenia autora prekladu.

3 „Ich bin ein Mann! Wer ist es mehr?“ Männlichkeitskonzepte in der deutschen Literatur vom Mittelalter bis zur Gegenwart, red. B. Hindinger, M.M. Langner, München 2011.
} 
Centrálnym aspektom štúdií je komplexný proces konštrukcie mužských rodových rolí a napätie, ktoré tento proces sprevádza. Ich autori a autorky sa zaoberajú otázkami, či sú literárne konštrukcie maskulinity primárne určované biologickými danostami, psychickými a fyzickými vlastnostami mužov a žien, alebo ich sociálne a kultúrne podmienenými rolami. Ako ukazujú analýzy literárnych a jazykových konštrukcií mužskosti a spoločensko-historického ukotvenia procesu ich vytvárania, nie sú koncepty maskulinity síce konštantné a dochádza kich rekonštrukcii či prekódovaniu, ale predsa len vykazujú evidentnú mieru stability v rôznych literárno-historických etapách. Literárnohistorický prístup transparentne prezentuje tieto konštanty, ale súčasne čitatel'a senzibilizuje voči kontextovým zmenám ich literárnej reprezentácie.4 Štúdie sa koncentrujú predovšetkým na prozaické a dramatické žánre a zameriavajú sa na možnosti literárneho stvárnenia maskulinity a jej konfliktov, na motívy mužskosti, komponenty obrazu muža, maskulínne stereotypy, premeny vzorových mužských rolí, prispôsobovanie sa tradícii a narúšanie konvencií. Pohybujú sa od ideálneho obrazu rytiera cez sebaironické postavy literárnych frašiek či svetáctvo ranej moderny až po „polymorfnú mužskost“" 5 konca dvadsiateho storočia. Už rytierske eposy podla analýz ukazujú, že sociálne a individuálne koncepty mužskosti môžu byt navzájom v konflikte, že mužskost' môže byt' situovaná na osi strach - agresia, nedotknutel'nost' - smrtel'nost', moc - bezmocnost't .

Východiskovou bázou literárnovedných analýz mužskosti v novom tisícročí teda nie je maskulinita ako niečo prirodzene dané, nadčasové a nemenné, ale mužskost’ ako sociálna, diskurzívna konštrukcia, resp. konfigurácia sociálnych a kultúrnych praktík a reprezentácií. Ked’že ide o koexistenciu rôznorodých modelov mužských rolí vpluralitnej spoločnosti, ale aj o rozmanitost' historických konceptov mužskosti, pojem maskulinity sa vnemeckom literárnovednom diskurze čoraz častejšie objavuje v pluráli. Toni Tholen, profesor pre literárnu vedu a didaktiku literatúry na Univerzite $\mathrm{v}$ Hildesheime, publikoval výsledky svojich výskumov literárnych konštrukcií mužskosti vo viacerých súborných prácach, z ktorých najsilnejšie rezonovala monografia Männlichkeiten in der Literatur. Konzepte und Praktiken zwischen Wandel und Beharrung [Maskulinity $\mathrm{v}$ literatúre. Koncepty a praktiky medzi zmenou a

4 Ibidem, s. 9.

5 Ibidem, s. 256.

${ }^{6}$ Ibidem, s. 43-64. 
zotrvačnostou]7. Monografia obsahuje literárnovedné analýzy mužskosti zo systematickej, ale aj historickej perspektívy. Systematicky explikuje základné dimenzie prístupu k konfiguráciám mužskosti v literárnych textoch a v historickom pohlade skúma podoby mužskosti v literárnych textoch od šest'desiatych rokov dvadsiateho storočia až po súčasnost'.

Tholen používa pojem „mužské spôsoby existencie“ v nadväznosti na práce Andrey Maihoferovej, podl'a ktorej je rod „historicky daný spôsob existencie“8. Používaním množného čísla maskulinity sa zároveň dištancuje od téz výskumov z devätdesiatych rokov, podl'a ktorých sa mužský ideál vytvoril v literatúre už koncom 18. storočia a dodnes určuje kultúrny výklad. Tholen považuje tento maskulínny stereotyp s charakterovými vlastnostami ako odvaha, sila vôle, zmysel pre čest', ale aj s duševno-telesnými znakmi ako zdravý vzhl'ad a sebakontrola, za neadekvátny, ak má íst' o hlbšie analýzy mužskosti v literatúre, pretože ideál fixuje mužskost’ iba vjednom univerzálnom maskulínnom vzorci9. Nielen súčasná literatúra však ponúka stvárnenie nespočetných podôb mužskosti a meniacej sa pozície muža v rodových štruktúrach. Maskulinity v pluráli sa týkajú tiež procesov v rámci recepcie literárnych textov, ktoré sa tak nemusia koncentrovat' na hl'adanie dominantného obrazu muža, ale majú byt’ otvorené vnímaniu nuáns celého spektra často ambivalentných rodových obrazov a vztahov. To nevylučuje kritickú reflexiu normatívnych obrazov mužskej dominancie, ale umožňuje literárnej vede zároveň uchopit’ mužskost’ ako „konštrukt mnohých podôb"'10.

Hladanie odpovedí na t’ažiskové otázky premien a konštánt mužských spôsobov existencie je však podl'a Tholena možné iba v prieniku rôznych vedeckých disciplín. Literárnovedné koncepty spája predovšetkým so sociologickými štúdiami maskulinity a aplikuje pritom spoločné relevantné aspekty. Prvým je relacionalita, ktorá ako výrazná črta konštruktov mužskosti odkazuje pri vnímaní rolí a postavenia mužskosti na konštitutívnu úlohu vztahov mužských postáv s ostatnými, ženskými aj mužskými, postavami a na procesnost’ týchto vztahov. Obraz muža nie je daný tradičnou zjednodušujúcou charakteristikou postavy, tá často neukáže nič iné, iba rodové stereotypy. Mužskost’ sa v literárnom texte konfiguruje

\footnotetext{
7 T. Tholen, Männlichkeiten in der Literatur. Konzepte und Praktiken zwischen Wandel und Beharrung, Bielefeld 2015.

${ }^{8}$ A. Maihofer, Geschlecht als Existenzweise. Macht, Moral, Recht und Geschlechterdifferenz, Frankfurt a. M. 1995, s. 85 .

9 T. Tholen, Männlichkeiten..., op. cit., s. 12, s. 51.

${ }^{10}$ Ibidem, s. 13.
} 
v spleti vztahov a perspektív, je pohyblivá, odvíja sa aj z relácií medzi dominantne mocenskou hegemonickou a marginálnou či minoritnou maskulinitou. Do literatúry sa však tieto sociologické kategórie, prirodzene, neprenášajú priamo, v texte je nutné ich vnímat’ ako esteticky stvárnené a polyperspektívne.

Ďalší kl'účový aspekt, naratívnost', sa objavuje už v prácach Waltera Erharta $\mathrm{k}$ mužskosti v rodinných románoch na prelome tisícročí1 ${ }^{11}$. Podl'a Erharta sa mužskost' prezentuje ako príbeh, dá sa čítat' ako naratívne štruktúrovaný text a stvárnit’ ako sled naratívnych modelov a konfigurácií12 ${ }^{12}$ Ak je mužskost’ naratívna štruktúra, musia analýzy literárnych textov zohl'adňovat', že narácie pozostávajú z mentálnych naratívnych elementov (scripts), ovplyvnených kultúrnou a sociálnou praxou, „ktoré do jednotlivých literárnych textov vpisujú určité dlhoveké vzorce mužskosti, opakujúce sa mužské spôsoby správania a typické mužské životné príbehy“13. Ak sa mužská identita, obrazy či roly mužov, ako aj mýty o mužoch formujú predovšetkým naratívne, potom pri ich analýze pripadá literárnej vede významná úloha. Pre pochopenie konštrukcie mužskosti je pritom nezanedbatel’né, $\mathrm{v}$ akej forme sú obrazy mužov naratívne inscenované. V náročných literárnych textoch nezriedka nachádzame komplexné, až vnútorne protirečivé konštrukcie mužskosti. ${ }^{14}$ Literárne žánre ako rodinné romány, v ktorých zohráva úlohu medzigeneračná kontinuita, resp. zmena, a v ktorých sa nezriedka zrkadlí rodová politika a sociokultúrne postoje konkrétnych historických období, rovnako ako biografie otcov a autobiografické záznamy k téme otcovstva, sprevádzajúce spoločenskú diskusiu o tzv. „nových otcoch“, majú podla Tholena dôležitú funkciu pri diskurzívnom formátovaní mužskosti. Ich kritický výklad môže narúšat normatívne predstavy mužskosti a vplývat' na transformáciu až redefinovanie maskulinít. $\mathrm{V}$ tom literárny vedec vidí uvol'nenie potenciálu literatúry, ked' lektúra literárneho textu prebieha ako kritická reflexia foriem

${ }^{11}$ W. Erhart, Familienmänner. Über den literarischen Ursprung moderner Männlichkeit, München 2001.

${ }^{12}$ Ibidem, s. 53-54.

${ }_{13}$ T. Tholen, Männlichkeiten..., op. cit., s. 16.

14 Ibidem, s. 69-71, s. 155-164. Ako príklad uvádza Tholen román W. G. Sebalda Austerlitz, ktorý rozpráva príbeh židovského chlapca zachráneného pred nacistami v tajnom detskom transporte do Anglicka a tým traumatizovaného na celý život. Traumatické zážitky robia Austerlitza reprezentantom marginalizovanej mužskosti, zároveň však ako intelektuál vykazuje znaky hegemonickej maskulinity. 
hegemonickej maskulinity a zároveň otvorenie sa alternatívnym, nehegemonickým formám mužskosti v umeleckom texte.

V naratívnych konštrukciách mužskosti, ktoré sa vyznačujú výraznou ambivalentnostou a rozporuplnost'ou, možno rozoznat' nezamenitel'ný utopický potenciál iných mužských spôsobov existencie. Čoraz častejšie sa v literárnych textoch objavujú aj estetické modely marginalizovanej mužskosti, ktorá nie je následkom krízy maskulinity, ale naratívnym stvárnením trvalého stavu exklúzie nehegemonických mužských postáv alebo zobrazením ich života na okraji najmä $\mathrm{v}$ dôsledku sociálnych deformácií. Na spoločnej negatívnej skúsenosti $\mathrm{s}$ hegemonickou maskulinitou však podl'a Barbary Stieglerovej15 môžu spočívat’ spojenectvá medzi mužmi a ženami významné aj pre rodovú politiku.

Máloktoré médium je rovnako ako literatúra schopné spochybnit’ stereotypné konštrukty rodovo podmienenej identity. Literárne texty reflektujú tiež zmeny postojov mužov $\mathrm{v}$ pracovných pozíciách a pri starostlivosti v rodine, ktoré tažiskovo skúma sociológia, a zároveň tieto rodovo príznakové oblasti nanovo modelujú.

Vedci rôznych disciplín upriamujú pritom svoj záujem na málo tematizovanú úlohu mužov pri starostlivosti o deti, rodiča alebo partnera či pri iných opatrovatel'ských činnostiach a jej vplyv na rezistentné koncepty mužskosti. Zdanlivo stabilné, od počiatkov industriálnej spoločnosti platné rozlíšenie zárobkovej činnosti a s ňou spojenej profesionálnej kariéry ako mužskej sféry na jednej strane a na druhej strane starostlivosti o rodinu ako ženskej sféry sa v transdisciplinárnej perspektíve ukázalo ako zúžené a zjednodušujúce. Literárnovedné analýzy demonštrujú príklady prepojenia sféry starostlivosti o blízku osobu s mužskými konceptmi na rozdiel od jej tradičných ženských konotácií už od počiatkov moderny. Sociológovia ${ }^{16}$ analyzujú, ako so zásadnými zmenami zamestnávania v súčasnosti súvisia zmeny konvenčných mužských životných polôh, strata výlučnej pozície živitel'a, zabezpečujúceho rodinu ekonomicky, no neangažovaného $\mathrm{v}$ rodinnom živote, neparticipujúceho na výchove detí, rovnako modifikácia del'by práce v rodine meniaca zároveň sféry vplyvu muža a ženy, ako aj zmena normatívneho obrazu autoritatívneho otcovstva smerom ku

\footnotetext{
15 B. Stiegler, Geschlechter in Verhältnissen. Denkanstöße für die Arbeit in Gender Mainstreaming Prozessen, Bonn 2004, s. 16, https://library.fes.de/pdf-files/asfo/o2613.pdf [dátum prístupu: 20.01.2021].

${ }^{16}$ S. Scholz, Männlichkeitssoziologie. Studien aus den sozialen Feldern Arbeit, Politik und Militär in Deutschland, Münster 2012.
} 
konceptu nového aktívneho otcovstva. Práve výskum otcovstva zažíva v druhej dekáde nového tisícročia nárast, aj ked’ nie vždy pritom pracuje s mužskost’ou ako sociálnym konštruktom a vztłahom otcovstva a mužskosti. Sociológ Michael Meuser ${ }^{17}$ poukazuje na aktuálne štatistické údaje, podl'a ktorých 30-35 percent úloh spojených so starostlivostou o deti preberajú muži, ale tiež na prevažujúce postoje zamestnávatel'ov, ktorí napríklad dlhšiu otcovskú dovolenku stále považujú za neštandardnú. Aktívne, angažované otcovstvo preto muža často nezbavuje konvenčného statusu živitel'a rodiny.

Toni Tholen vo svojich analýzach mužských spôsobov existencie kategorizuje rôzne typy mužov v literatúre. Od Reawyn Connellovej preberá označenie „frontmanov“, vyznačujúcich sa zvláštnou agresivitou, stupňovaným egocentrizmom, nízkym pocitom zodpovednosti voči druhým, uvol'nenou sexualitou ${ }^{18}$. Ich literárne reprezentácie nachádzame najčastejšie v postavách manažérov či iných profesií profitujúcich vglobálnom podnikatel'skom prostredí. Na druhej strane situuje Tholen nositelov kvalitatívnej zmeny mužských spôsobov existencie, jednak typy marginalizovaných mužov ${ }^{19}$, ktorých výskum z literárnovednej perspektívy je nutné ešte prehíbit’, a jednak typy vyššie charakterizovaných „nových mužov“ a „nových otcov“, ktorým však aj sociologické výskumy priznávajú ešte stále status ideálu. Literárne texty stvárňujúce aktívne otcovstvo sa však v nemeckej literatúre už objavujú, nápadne ich pribúda od prelomu tisícročí a charakterizuje ich špecifická naratívna konštrukcia.

Predovšetkým autori narodení v šest'desiatych rokoch dvadsiateho storočia podávajú $\mathrm{v}$ autobiografických textoch svedectvo o tom, ako narodenie dietata zmenilo ich život, ich zmýšlanie a emocionálne prežívanie. Píšu často vel'mi otvorene o svojich obavách aj radostiach, o úsilí zosúladit’ participáciu v rodinnom živote a nerušenú tvorivú prácu. Narodenie dcéry opisuje významný básnik strednej generácie Durs Grünbein vo svojom denníkovom texte Das erste Jahr. Berliner

\footnotetext{
17 M. Meuser, A. Buschmeyer, Neue Väter und verunsicherte Männer - Männlichkeit in geschlechtersoziologischer Perspektive, https://www.soziopolis.de/beobachten/gesellschaft/ artikel/neue-vaeter-und-verunsicherte-maenner-maennlichkeit-ingeschlechtersoziologischer-perspektive/ [dátum prístupu: 15. 11. 2020].

${ }_{18}$ T. Tholen, Männlichkeiten..., op. cit., s. 54 .

19 Die soziale Konstruktion von Männlichkeit. Hegemoniale und marginalisierte Männlichkeiten in Deutschland, red. N. Baur, J. Luedtke, Opladen 2008. Na rozdiel od špecifikácie u Connellovej autori bez bližšieho zdôvodnenia zahŕňajú pod koncept marginalizovanej mužskosti mladých mužov, nízke spoločenské vrstvy, etnické menšiny a neheterosexuálnych mužov.
} 
Aufzeichnungen [Prvý rok. Berlínske poznámky] ${ }^{20}$ ako znovuobjavenie samého seba ako muža a zároveň spochybnenie vlastnej autonómie. Tholen vyzdvihuje senzibilnú literárnu reflexiu otcovskej roly vo viacerých textoch „nových otcov“, poukazuje však zároveň na minimálne posuny tradičnej roly mužského autorstva. Žena a matka v textoch „nových otcov“ väčšinou symbolicky absentuje ${ }^{21}$, aj Durs Grünbein si od skúseností a emočného sveta partnerky a dcéry zachováva vnútorný odstup. Napriek tomu súčasné autobiograficky ladené texty o otcovstve skrývajú dôležitý potenciál stvárnenia zmenených obrazov mužskosti, čím sa evidentne odlišujú od starších textov napríklad rebelujúcej generácie 68, ktorá rozpor medzi intelektuálnou aktivitou a úlohou otca rodiny vnímala vel’mi výrazne, až antagonisticky. Literárne texty s témou otcovstva zo sedemdesiatych a osemdesiatych rokov dvadsiateho storočia demonštrujú napätie medzi umeleckými ambíciami autorov a mužskými rolami $\mathrm{v}$ rodine a bezvýchodiskovost’ napätej situácie. Dieta a partnerka rušia spisovatel’a pri práci, brzdia ju, kradnú umelcovi čas, ktorý má byt’ venovaný kreatívnej činnosti, nakoniec zostáva pocit vnútornej prázdnoty. Za míl'nik v literárnej reflexii spojenia mužskej roly v rodine s literárnou činnostou považuje Tholen Kindergeschichte [Detský príbeh] ${ }^{22}$ Petra Handkeho, „poviedku o realizácii - v žiadnom prípade nie iba idylickej - podoby života, v ktorej literárne činný umelec mnoho rokov svojho života zdiel'a svoj priestor a čas s vlastným dietatom a pritom sa mení aj spôsob jeho práce a formy jeho písania“23 Poviedka spracúva autobiografické skúsenosti autora a jeho ambivalentného vztahu s vlastnou dcérou, ktorú desat’ rokov vychovával sám. Protagonista nakoniec nachádza poetickú odpoved’ na novú rodinnú situáciu v novo objavenej podobe večerného, fragmentárneho písania.

Ako je z uvádzaných príkladov evidentné, literárnovedné skúmanie mužskosti sa v Nemecku vyznačuje výraznými interdisciplinárnymi až transdisciplinárnymi prienikmi. Sú spojené napríklad s výskumnou pracovnou skupinou AIM Gender ${ }^{24}$, ktorá je založená na kooperácii vedcov z historických vied, literárnej vedy, kulturológie, politológie a sociológie a na

${ }^{20}$ D. Grünbein, Das erste Jahr. Berliner Aufzeichnungen, Frankfurt a. M. 2001.

${ }^{21} \mathrm{~T}$. Tholen, Männlichkeiten..., op. cit., s. 75.

22 P. Handke, Kindergeschichte, Frankfurt a. M. 1981.

23 T. Tholen, Männlichkeiten..., op. cit., s. 86.

24 Arbeitskreis für interdisziplinäre Männer- und Geschlechterforschung - Kultur-, Geschichtsund Sozialwissenschaften AIM GENDER, https://www.uni-bielefeld.de/soz/personen/ lengersdorf/aim_gender.html [dátum prístupu: 15. 11. 2020]. 
interdisciplinárnom prístupe k téme mužskosti a jej vplyvu na kultúru a spoločnost' v minulosti i súčasnosti. Skupina sa zameriava nielen na vonkajškové javy mužskej hegemónie, ale aj na skúsenosti mužov s vnútenými obrazmi mužskosti.

Aké rozhodujúce sú kultúrne koncepty mužskosti pri hodnotení správania mužov, ukázala v súčasnom nemeckom spoločenskom diskurze azda najvýraznejšie reflexia násilností počas silvestrovskej noci 2015/2016 v Kolíne. Problematické správanie mužov bolo okamžite označené ako kultúrne cudzie. Mužskost’ vnímaná ako cudzia sa spájala s archaickostou, kým mužskost' „vlastných“ sa mohla prezentovat’ ako osvietená, progresívna, moderná. Na druhej strane kritici týchto zjednodušených hodnotení poukazovali na podobné praktiky vlastnej spoločnosti v určitých sociálnych vrstvách alebo vekových skupinách. Diskurz bol podnetom, aby AIM Gender analyzoval mužskost’ ako diskurzívnu konštrukciu medzi rôznymi kultúrami z historickej, sociologickej, etnologickej a tiež literárnovednej perspektívy ${ }^{25}$.

Jednou z tažiskových tém výskumu bol vzt’ah mužskosti a násilia, predovšetkým s dôrazom na reflexiu marginalizovania mužskej zranitel'nosti. Ked’že muži dominujú nielen v štatistikách páchatel'ov kriminálnych činov, ale aj ich obetí, ukazuje sa, že súvislost' medzi mužskostou a násilím sa dá diferencovane vysvetlit, iba ak muži nie sú vnímaní iba ako páchatelia, ale aj ako obete násilia. Vo vzt’ahu k zranitel'nosti je rozdiel medzi pohlaviami nad’alej najviditel'nejšou rozlišovacou kategóriou. Kultúrne konštrukcie mužskosti a ženskosti určujú ženské telo ako zranitelné a mužské ako schopné zranit. V konvenčných rodovo polarizovaných očakávaniach môže byt' zranitel'ný iba nezrelý muž. Príklady, ktoré nezodpovedajú tejto binárnej klasifikácii, sú v diskurzívnych praktikách ignorované, samými mužmi vnímané ambivalentne, potláčané až negované. Až nové tisícročie prinieslo štúdie zaoberajúce sa formami ženského násilia ${ }^{26}$ alebo mužskými skúsenostami v pozícii obete, ktoré sa však vyznačujú inými symbolickými konotáciami ako mužské násilie na ženách a ženský status obete. AIM Gender sa zameral aj na tematizovanie mužskej sexuality v kontexte komplexných otázok rodovej identity a jej konštrukcie v rámci diskurzívnych praktík, v ktorých sa mužská sexualita oddeluje od intímnych emocionálnych väzieb a spája s násilím.

\footnotetext{
25 Výsledkom bola konferencia Männlichkeiten zwischen Kulturen https://www.akademiers.de/fileadmin/veranstaltungen/faltblatt_pdf/21170_programm.pdf_[dátum prístupu: 15. 11. 2020].

${ }^{26}$ B. Schwithal, Weibliche Gewalt in Partnerschaften, Norderstedt 2005.
} 
Dôležitým predmetom výskumu sa v ostatnej dekáde stali v rôznych vedeckých disciplínach emócie. Výskum emócií vychádza z predpokladu, že city majú síce fyziologickú bázu, ale sú zároveň sociálnokultúrnymi fenoménmi, a preto tiež podliehajú výrazným historickým zmenám. Každá kultúra vníma inak legitímnost’ a nelegitímnost’ určitých emócií a pozná osobitné emočné pravidlá v sociálnych interakciách. Analýza kultúrneho kódovania emócií a ich výskum v špecifických sociálnych kontextoch sú hlavnými oblastami súčasného výskumu emócií.

Pri výskume súvislosti medzi rodom a emóciami je dôležitá história pojmu emócie. V moderných západných spoločnostiach sa v diskurzívnej rovine konštituovalo spojenie ženskosti s emocionalitou a mužskosti s racionalitou, dokonca spojenie „temných“ emócií ako strach, smútok, utrpenie, hanba s feminitou. Takéto rodovo zatažené binárne kódovanie viedlo $\mathrm{k}$ tomu, že sa mužské city dlho vo výskume obchádzali alebo negatívne tematizovali, napríklad ako potláčanie citov či, naopak, uvol’nenie mužských afektov. Naopak, emočne chladným ženským postavám, napríklad počas novej vecnosti v medzivojnovom období, sa nevenovala pozornost'. Novšie práce nemeckých literárnych vedcov využívajú výsledky interdisciplinárnych výskumov mužskosti, aby polaritné kultúrne kódy binárnych párov maskulinita a racionalita na jednej strane a feminita a emocionalita na strane druhej preskúmali na báze dekonštruktivistických východísk. Tento zámer sleduje napríklad zborník Literarische Männlichkeiten und Emotionen [Literárne maskulinity a emócie]27, ktorého štúdie predstavujú zväčša mužské postavy s intenzívnym emočným prežívaním a prevažujúcim smútkom a bolest’ou, čím kontrastujú so stereotypnými konštruktmi emočne deficitnej mužskosti. Aspekt emocionality je možné skúmat’ predovšetkým $\mathrm{v}$ rôznych konšteláciách vztahov postáv, v ktorých sa namiesto hegemonickej maskulinity demonštrujú alternatívne mužské role. Viacero štúdií poukázalo na prítomnost’ celej škály emócií v sociálnej konštrukcii mužskosti, ale predovšetkým na nevyhnutnost' skúmania estetického a sociálneho kontextu konkrétneho historického obdobia a jeho vplyvu na určité rodovo podmienené kódovanie emócií v literárnom texte.

Spolu s mnohými inými vedcami sa aj tu často citovaný Toni Tholen domnieva, že kríza mužskosti trvá už začiatkov moderny a je vlastne šifrou pomalého procesu transformácie rodových vztahov. Zastáva chápanie krízy

\footnotetext{
${ }^{27}$ Literarische Männlichkeiten und Emotionen, red. T. Tholen, J. Clare, Heidelberg 2013.
} 
ako „diskurzívneho označenia historického momentu, vktorom sa nefungovanie sociálnych vztahov, predovšetkým vztahov medzi pohlaviami, vníma ako obzvlášt' výrazné“28 Súčasná kríza je podl’a neho výsledkom kulminujúceho vývoja najmä vzhl'adom na „nové, obzvlášt agresívne formy hegemonickej maskulinity“29 globálneho charakteru a konzekvenciou neúčinnej kritiky dominantných štruktúr mužskosti. Tholen hladá odpoved' na krízu mužskosti v konfigurácii „dialogickej subjektivity“30, mužskosti, ktorá sa v dialógu, s láskou a starostlivostou venuje sebe aj druhým, a to nie v zmysle protektívnej maskulinity, ale ako výraz oslobodenia sa od konvenčných rodových rol. Hladanie takých kultúrnych a estetických konfigurácií v súčasnej nemeckej literatúre, ktoré obsahujú „utopické stopy“31 inej mužskosti, iného, nehegemonického mužského spôsobu existencie a iných rodových vztahov, by sa malo stat’ naliehavou úlohou literárnej vedy.

Štúdia je výsledkom riešenia projektu Vedeckej grantovej agentúry Ministerstva školstva, vedy, výskumu a športu Slovenskej republiky 1/o747/18 Obrazy sveta ako výskumná doména humanitných vied. Produkcia, distribúcia, recepcia a spracovávanie obrazov sveta.

\section{Literatúra / References}

Baur N., Luedtke J., red., Die soziale Konstruktion von Männlichkeit. Hegemoniale und marginalisierte Männlichkeiten in Deutschland, Opladen 2008, 290 S.

Borutta M., Verheyen N., red., Die Präsenz der Gefühle. Männlichkeit und Emotion in der Moderne, Bielefeld 2010, $336 \mathrm{~S}$.

Connell R., Der gemachte Mann. Konstruktion und Krise von Männlichkeiten, Wiesbaden 2015, 375 S.

Connell R. W., Messerschmidt J. W., Hegemonic maskulinity. Rethinking the Concept, „Gender \& Society” 2005, No. 6 (16), s. 829-859.

Erhart W., Familienmänner. Über den literarischen Ursprung moderner Männlichkeit, München 2001, 463 S.

Grünbein D., Das erste Jahr. Berliner Aufzeichnungen, Frankfurt a. M. 2001, 328 S. Handke P., Kindergeschichte, Frankfurt a. M. 1981, 137 S.

Hindinger B., Langner M.M., red., „Ich bin ein Mann! Wer ist es mehr?" Männlichkeitskonzepte in der deutschen Literatur vom Mittelalter bis zur Gegenwart, München 2011, 347 S.

${ }^{28}$ T. Tholen, Männlichkeiten..., op. cit., s. 47.

29 Ibidem, s. 47, s. 54 .

30 Ibidem, s. 48.

${ }^{31}$ Ibidem, s. 48. 
Horlacher S., Jansen B., Schwanebeck W., red., Männlichkeit. Ein interdisziplinäres Handbuch, Stuttgart 2015, $382 \mathrm{~S}$.

Maihofer A., Geschlecht als Existenzweise. Macht, Moral, Recht und Geschlechterdifferenz, Frankfurt a. M. 1995. 208 S.

Meuser M., Buschmeyer A., Neue Väter und verunsicherte Männer - Männlichkeit in geschlechtersoziologischer Perspektive, Soziopolis, 05. 01. 2017, https://www.soziopolis.de/beobachten/gesellschaft/artikel/neue-vaeterund-verunsicherte-maenner-maennlichkeit-in-geschlechtersoziologischerperspektive/ [dátum prístupu: 15. 11. 2020].

Scholz S., Männlichkeitssoziologie. Studien aus den sozialen Feldern Arbeit, Politik und Militär in Deutschland, Münster 2012, 291 S.

Schwithal B., Weibliche Gewalt in Partnerschaften, Norderstedt 2005, 404 S.

Stiegler, B., Geschlechter in Verhältnissen. Denkanstöße für die Arbeit in Gender Mainstreaming Prozessen, Bonn 2004, 35 S., https://library.fes.de/pdffiles/asfo/02613.pdf [dátum prístupu: 15.11. 2020].

Tholen T., Clare J., red., Literarische Männlichkeiten und Emotionen, Heidelberg $2013,226 \mathrm{~S}$.

Tholen T., Männlichkeiten in der Literatur. Konzepte und Praktiken zwischen Wandel und Beharrung, Bielefeld 2015, 215 S. 